\title{
Other Pilgrims: Sequels, Imitations, and Adaptations of The Pilgrim's Progress
}

\author{
Christopher E. Garrett
}

Associate Professor, Nevada State College, Henderson, Nevada, USA

\begin{abstract}
The Pilgrim's Progress by John Bunyan, a bestseller in seventeenth-century England, captured the imaginations of its readers and inspired imitations and spurious works. Since its inaugural publication in 1678, numerous sequels, continuations, and adaptations of The Pilgrim's Progress have been produced. This essay provides examples of those various forms, including prose, poetic, musical, and cinematic adaptations, sequels, and imitations.
\end{abstract}

Keywords- John Bunyan, The Pilgrim's Progress, sequels, adaptations, imitations, Second Part of the Pilgrim's Progress.

\section{INTRODUCTION}

Although Puritan preacher and author John Bunyan (16281688) popularized the pilgrimage motif in the late seventeenth century, he did not pioneer it. For example, thirteen years prior to the publication of Bunyan's The Pilgrim's Progress (1678), Symon Patrick revived the pilgrimage form in his Parable of the Pilgrim (1665). While the metaphor of the spiritual wayfarer was not Bunyan's invention, his tale of the pilgrim, Christian, captivated the minds of readers that surpassed other attempts. In the seventeenth century twenty-two editions of Bunyan's The Pilgrim's Progress were issued, totaling over 30,000 copies (Greaves, 2002, p. 377; Keeble, 1987, pp. 128-134). Not surprisingly, Bunyan's bestseller fueled the imaginations of many authors, who have penned and published numerous continuations, imitations, and adaptations over the past three centuries.

\section{MR. BADMAN}

At the conclusion of The Pilgrim's Progress, Bunyan tempts imitations by hinting that he was already considering a sequel: "But if thou shalt cast all away as vain, / I know not but 'twill make me Dream again" ( $P P$, p. 164). However, two years later, when he publishes The Life and Death of Mr. Badman (1680) as a sequel, it does not satisfy his readership's desires for more adventurous pilgrimaging. As one who traverses toward eternal damnation, Mr. Badman serves as a foil to Christian. "Badman's struggles are fundamentally different than Christian's," Richard Greaves observes, "for his battles are waged from the perspective of the wicked combating the good" (Greaves, pp. 598-599). After Bunyan offers the relatively unsuccessful $M r$. Badman, which did not measure up to the standards that readers expected in a sequel, other authors attempt to fulfill that need.

At the conclusion of The Pilgrim's Progress, Bunyan tempts imitations by hinting that he was already considering a sequel: "But if thou shalt cast all away as vain, / I know not but 'twill make me Dream again" ( $P P$, p. 164). However, two years later, when he publishes The Life and Death of Mr. Badman (1680) as a sequel, it does not satisfy his readership's desires for more adventurous pilgrimaging. As one who traverses toward eternal damnation, Mr. Badman serves as a foil to Christian. "Badman's struggles are fundamentally different than Christian's," Richard Greaves observes, "for his battles are waged from the perspective of the wicked combating the good" (Greaves, pp. 617-618). After Bunyan offers the relatively unsuccessful $M r$. Badman, which did not measure up to the standards that readers expected in a sequel, other authors attempt to fulfill that need.

\section{SECOND PART OF THE PILGRIM'S PROGRESS}

The best-known imitative sequel is The Second Part of the Pilgrim's Progress (1682) by T. S. While labeled as a sequel, it is really not a continuation of Bunyan's tale but rather one of the first literary critiques of the tinker's bestseller. T. S. seeks to improve the pilgrimage narrative by filling in the gaps that Bunyan omitted and seizing the opportunity to revise the allegory in order to correct the theological deficiencies T. S. detects in Part One. In this work T. S. emphasizes church organization, communion, and "the general rather than the particular call" (Tindall, 1964, p. 64).

The Second Part of the Pilgrim's Progress commences with a nine-page introduction wherein the 
narrator attempts to remedy the four major defects in Bunyan's allegory. In a systematic fashion, T. S. offers meditations on the creation, the fall and redemption of mankind, the pain and suffering of mortality, and the difficulty of saving souls. After rising to the heights of heavenly meditation, the narrator, overcome with grief, falls asleep and dreams.

In his dream, the protagonist (Reprobate) embarks on a pilgrimage. Reprobate converses with various characters and discovers two paths: one that leads to the Kingdom of Darkness and the other to Celestial Paradise. He sees a group of people dancing dangerously close to the pit of Hell who are warned to "flee from the wrath to come," but several fall into the Pit. Reprobate hears a voice like thunder, urging him to repent and become a pilgrim. He encounters an intimidating Fiend, who attempts to persuade Reprobate to forsake his pilgrimage. On the way toward the City of Refuge, Reprobate climbs the hill of Self-Denial; but finding it too challenging, the pilgrim turns to the easier and closer mountains of Confession, Prayer, Amendment of Life, Holy Duties, and Ordinances. After praying, the pilgrim hearkens to an inner voice that urges him to the City of Refuge because Jesus is there ready to greet him. Upon his arrival, the pilgrim makes a covenant with Christ, receives new clothing, a new heart, a new name (Believer), a stone, and the promise of eternal life. After dining with the King (Jesus) at the Royal Feast, with its symbolic dishes, Believer continues his journey and approaches Paradise. First, he must pass through a river; aided by Faith and Hope, Believer is embraced by the Redeemer and presented to the Father.

It is important to note that The Second Part of the Pilgrim's Progress by T. S. is not a spurious, but rather an imitative work. This is consistent with T. S.'s career as an imitative sequel writer: T. S. "establishes his authorial identity as an imitative writer who actively participates in the genre of Protestant meditational literature by providing sequels (e.g., Divine Breathings...the Second Part and The Second Part of the Pilgrim's Progress)" (Garrett, 2007, p. 158). T. S. does not attempt to deceive readers into thinking that Bunyan is the author. Instead, T. S.'s objective is to focus not only on providing a critical but also an imaginative reading of Bunyan's allegory that emphasizes and promotes the practice of meditation. He achieves this by presenting a narrative that, while intentionally less adventurous than Bunyan's, includes numerous, deliberate pauses to guide the reader in meditatively reflecting on what has been presented (Garrett, p. 158). T. S. does not intend to captivate the reader with his narrative, but rather he promises in the opening pages of his "Apology" that he will offer his sequel as "Meditations" (T. S., 1682, p. xii). Nearly ninety pages are penned before the pilgrim reaches the gate and officially begins his journey toward heaven. Although those frequent pauses frustrate some critics, The Second Part of the Pilgrim's Progress attracted an audience that merited at least five editions in England and Scotland within fourteen years.

Scholars have speculated about the identity and religious affiliation of T. S. Based on my extensive research on the attribution history, I have discovered no evidence to suggest that T. S. is Thomas Sherman. After tracing the trail of scholarship back to the origins of this attribution, I posit that a ghostwriter was invented named Thomas Sherman, whose biographical details cannot be determined (Garrett, 2014, pp. 191-216). Furthermore, the common practice by some readers of labeling T. S. as a General Baptist is also questionable. There is no Thomas Sherman listed in the directory of Baptist ministers housed at the Regents Park College Library in Oxford, England. Instead, it is possible that T. S. was a member of the Church of England who was sympathetic toward Puritanism. For example, Susan Cook detects a style that is "remarkably Anglican" in The Second Part of the Pilgrim's Progress by T. S. Its structure, Cook argues, is "structurally linked to the Book of Common Prayer and the prescribed homilies of the Church of England" (Cook, 1997, pp. 205-207).

In any case, regardless of the authorial identify and religious leanings of $\mathrm{T}$. S., the impact that this anonymous author had on Bunyan is what needs to be emphasized. First of all, The Second Part of the Pilgrim's Progress prompts Bunyan to write his own authentic sequel, one that follows more closely what readers expected in such a project. Bunyan read (or at least was aware of) T. S.'s work and other imitative sequels and adaptations because he mentions them in his apology to his The Pilgrim's Progress... The Second Part: "Tis true, some have of late, to Counterfeit / My Pilgrim, to their own, my Title set; / Yea others, half my Name and Title too; / Have stitched to their Book, to make them do" (PP, 168). Secondly, as U. Milo Kaufmann has observed, Bunyan emphasizes occasional meditation in The Second Part of the Pilgrim's Progress much more than in the first part (Kaufmann, 1966, p. 188). This attention to meditative writing shows that T. S., who promotes and stresses the practice of meditation in his The Second Part of the Pilgrim's Progress, may have influenced the style of Bunyan's sequel. 


\section{THE PILGRIM'S GUIDE}

But T. S. was not the only opportunistic author to publish an imitative sequel. Early in 1684, John Dunton published The Pilgrim's Guide from the Cradle to His Death-Bed: With His Glorious Passage from thence to the New Jerusalem. Represented to the Life in a Delightful New Allegory, Wherein the Christian Traveller is More Fully and Plainly Directed than yet he Hath Been by Any in the Right and Nearest Way to the Celestial Paradise. The narrative, related in first person by the pilgrim, describes a journey to the Celestial City; the pilgrim meets a guide and other characters such as Piety, Devil, World and Flesh, Lackimony, and Self-Deceit. Also in that same year, Thomas Passinger offers a twenty-two-page abridgement of Bunyan's first part of The Pilgrim's Progress.

\section{THE PILGRIM'S PROGRESS: THIRD PART}

At the close of his sequel, The Pilgrim's Progress...The Second Part, Bunyan once again alludes to the possibility of another narrative, perhaps a third installment: "Shall it be my Lot to go that way again, I may give those that desire it, an Account of what I here am silent about; mean time I bid my Reader Adieu" $(P P, 311)$. Unfortunately for his readers, Bunyan remained silent and opted not to dream again and revisit the pilgrimage motif as an author. On 31 August 1688, Bunyan passed away after battling an illness-described as a fever and distemper (probably influenza or pneumonia) - for several weeks (Greaves, pp. 598-599). By 1688 part one of The Pilgrim's Progress continued to attract readers, and that same year Ponder issued an eleventh edition. In comparison, Bunyan's sequels_-The Life and Death of Mr. Badman and The Second Part of the Pilgrim's Progresshad merited only two editions each. Voracious readers craved more of the pilgrimage allegory, and opportunistic writers and booksellers sought to satiate those appetites.

In 1693, the spurious work, The Pilgrim's Progress From This World to That Which is to Come: The Third Part, appears in print, claimed by an anonymous author who uses the initials 'J. B.' not on the title page but rather in the 'Preface to the Christian Reader.' Early editions of The Third Part included, as an appendage, The Life and Death of John Bunyan, one of the first biographies published on Bunyan. The title page and frontispiece of The Third Part contain symbols that could deceive the reader into thinking that its author was Bunyan. First, the subject of the frontispiece is almost identical to the illustration found in Part One, featuring Bunyan the dreamer, with his eyes closed, resting his head on hand, and above the dreamer's head is the City of Destruction. Second, although no author is listed with a by-line on the title page, the name "John Bunyan" (inserted there as part of the title of the biographical sketch) attracts the reader's attention due to the large font size and bold lettering. Therefore, because "John Bunyan" is positioned in the lower part of the title page where you would normally find the author's name, along with the accompanying tag, "Author of the First and Second Part; this completing the whole Progress," and upon recognizing the image of his face on the opposite page, it would be easy for a reader to assume that Bunyan was the author of this work. On the title page of the first edition, J. Blare is one of three booksellers identified; according to several scholars, Blare was notorious for printing spurious texts (Harrison, 1941, pp. 73-81; Greaves, pp. 617-618).

The author of The Third Part opens the narrative with the following lines: "After the two former Dreams concerning Christian, and Christiana his Wife, with their Children and Companions Pilgrimage from the City of Destruction to the Region of Glory; I fell asleep again, and the Visions of my Head returned upon me: I dreamed another Dream" (J.B., 1693, p. 1). The dreamer sees multitudes travelling from the City of Destruction toward the Wicket Gate; however, most of them return to their homes after experiencing various hardships and challenges, including the Slough of Despond. Tender Conscience, "a young man of an amiable Countenance," is one of the few travelers who continues to journey beyond the slough (J.B., p. 3).

The progress of Tender Conscience follows a path familiar to readers of Bunyan's The Pilgrim's Progress. For example, his wounds are healed in the House of Interpreter, and he passes by the cross and sepulchre. But there are also new places introduced such as the House of Mirth, House of Mourning, the Tower of Spiritual Pride, the Cave of Good Resolution, and Cave of Contemplation. During his journey, Tender Conscience carries a crutch that has magical power. Several companions join him on his pilgrimage, including Seek Truth, Yielding, Convert, Weary of the World, and Spiritual Man. At the Altar of Incense, Spiritual Man teaches them about the importance of prayer and cautions about using vain repetitions when praying. In some ways, Spiritual Man functions as a mentor-like character similar to Evangelist in Part One because he cautions and warns the pilgrims and teaches them important doctrines. For example, upon arrival at Vanity Fair, he tells Yielding that Vanity Fair is not the Celestial City, "but a meer Counterfeit; it is Babylon" (J.B., p. 109). Yielding is the major casualty at Vanity Fair-after excessive wine drinking, he dies suddenly at night. 
After passing through the Delectable Mountains, the pilgrims come to the Valley of Vain Opinions and meet Human Reason, who favors the natural world above the spiritual realm, preferring sense and reason above faith. Tender Conscience is seduced by the rhetoric of Human Reason, but Spiritual Man refutes the arguments presented by Human Reason and helps Tender Conscience discern the truth. Later, at the scene of Enchanted Ground, Convert reveals that he was previously named Atheist, the same character that Christian and Hopeful encountered on their pilgrimage. Before entering the Heavenly Jerusalem, the travelers must wade through the River of Death; in traversing the currents they are assisted by the Shining One.

J. B.'s The Third Part lacks the sense of urgency that Bunyan's Part One presents, wherein the pilgrim constantly cried, "What must I do to be saved?" While it follows, in many ways, the literary template Bunyan that established, The Third Part by J. B. presents a doctrine that is a more moderated Calvinism than the prequel. Bunyan's allegory is more complex than what we find in The Third Part. J.B. chooses a plainer style; the explanations are clear and overt. The Third Part, Cook observes, "does not ask its readers to participate in its interpretation but to be led along by the narrative" whereas "Bunyan demands active interpretation of his allegory" (Cook, p. 200).

J. B.'s Third Part rankled Nathaniel Ponder, publisher of each edition of The Pilgrim's Progress (both parts) during Bunyan's lifetime. In an advertisement printed on the verso of the title page of the thirteenth edition of Bunyan's The Pilgrim's Progress (1693), Ponder announces that J. B.'s The Third Part "is an Impostor, thrust into the World by a Nameless Author, and would insinuate to the Buyers, that 'tis John Bunyan's." Furthermore, Ponder claims to possess the authentic Third Part, "which, when convenient time serves, shall be Published." Evidently, Ponder was bluffing and never fulfilled that promise; there is no extant edition of an authentic Third Part written by Bunyan.

Notwithstanding this type of scrutiny by Ponder, for many years readers and printers must have assumed that The Third Part by J. B. was an authentic sequel. By the close of the eighteenth century it had appeared in fiftynine editions. In the latter part of the eighteenth century it was common for The Third Part by J. B. to be bound and sold with the first two parts by Bunyan (Cook, p. 175).

\section{POETIC ADAPTATIONS}

By the close of the seventeenth century, Bunyan's pilgrimage narrative had already been adapted into verse form. The Heavenly Passenger, or the Pilgrim's Progress from this World to that which is to come (1687) by M. S. contains over 700 verses in rhyming couplets and written in iambic pentameter. Remarkably faithful to the outline of the original text, M. S.'s poem briefly recalls many of the pilgrim's adventures but omits, for example, the teachings in the House of Interpreter and the discourse with Talkative.

Other poetic renditions would follow, including Ager Scholae's The Pilgrim's Progress in Poesie in two volumes (1697-98) and Francis Hoffman's The Pilgrim's Progress done into Verse (1706). The text of Hoffman's adaptation contains 143 pages of rhyming verse-couplets in iambic pentameter. Hoffman, in commendable fashion, efficiently translates Bunyan's prose into poetry. Even the scriptural passages that Bunyan cites are paraphrased and versified so that the rhyme scheme is maintained. Hoffman includes several excerpts of poetry found in prior illustrated editions of The Pilgrim's Progress printed by Ponder during Bunyan's lifetime. For example, when Faithful is on trial at Vanity Fair, the four lines of verse that accompanied the woodcut in the eleventh edition are cited verbatim: "Now Faithful play the man, speak for thy God, / Fear not the wicked's malice, nor their rod; / Speak boldly man, the truth is on thy side, / Die for it, and to life in triumph ride" ( $P P, 1688$, p. 112; Hoffman, 1706, p. 93). Notably, but not surprisingly, there are also numerous excerpts of poetry found in The Pilgrim's Progress that are altered to varying degrees by Hoffman; however, throughout this adaptation into verse both the story and the characters remain consistent with Bunyan's original prose narrative.

\section{THE PROGRESS OF THE CHRISTIAN PILGRIM}

In contrast to Hoffman's project in verse, the anonymous author of The Progress of the Christian Pilgrim ( $2^{\text {nd }}$ ed., 1702) exercises a different kind of creative license in prose, opting to modify the name of every character and place. For example, the pilgrim, Christianus (Christian), leaves the city of Ruine (City of Destruction) in pursuit of the Heavenly City (Celestial City). At the outset, two of his neighbors, Self-Will (Obstinate) and Easie (Pliable), attempt to dissuade Christianus from commencing his journey; the Director (Evangelist) guides Christianus in his progress. Unlike Bunyan's narrative in which the pilgrim's burden is released at the sight of a cross, The Progress of the Christian Pilgrim describes three crosses, and he finds that his burden is removed and found hanging on the middle cross, the one labeled as the cross of Jesus Christ. He travels first with Fidelius (Faithful) and later with 
Hopewell (Hopeful). At the Castle of Diffidence, Christianus and Hopewell encounter the Giant Desperation, but they are able to flee thanks to the Key of God's Promise. The Progress of the Christian Pilgrim also came packaged with a sequel about the pilgrimage of Christianus' wife, Christina (Christiana), and their four children.

\section{MISCELLANEOUS ADAPTATIONS}

As mentioned earlier, the catalog of adaptations and continuations of The Pilgrim's Progress includes hundreds of works that have been produced over the past three centuries. Although the objective of this essay is to provide readers with an introductory sampling of these enterprises, we would be remiss not to provide at least a cursory list of just a few of these titles. Authors from various denominations have written religious adaptations of Bunyan's allegory. Several examples include: Quaker Stephen Crisp's A Short History of a Long Travel, from Babylon to Bethel (1691); Francis Bugg's The Pilgrim's Progress, from Quakerism, to Christianity (1698); Congregationalist minister Joseph Morgan's The History of the Kingdom of Basaruah (1715); the founder of Methodism, John Wesley's abridgement of The Pilgrim's Progress (1743); and Universalist D. J. Mendle's The Adventures of Search for Life: A Bunyanic Narrative, as Detailed by Himself (1838). Among the numerous imitations that appeared in the eighteenth and nineteenth centuries were John Mitchell's The Female Pilgrim (1762), Mary Anne Burges' The Progress of the Pilgrim Good-Intent, in Jacobinical Times (1800), and Mark Twain's The New Pilgrim's Progress; A Book of Travel in Pursuit of Pleasure (1870). George Cheever's A Reel in a Bottle, for Jack in the Doldrums (1852) and George Wood's Modern Pilgrims: Showing the Improvements in Travel, and the Newest Methods of Reaching the Celestial City (1855) are just a few of the novels that imitate Bunyan's pilgrimage narrative. The Pilgrim's Progress has also been adapted in various forms for children, as Shannon Murray documents in her essay found elsewhere in this handbook.

In addition to fictional adaptations, political pundits have appropriated Bunyan's pilgrim in various mediums. For example, a 187-page treatise published anonymously in New England, Pilgrim's Progress in the Last Days (1843), exposes the injustice of slavery. In 1844 a Harper's Weekly political cartoon titled 'Pilgrim's Progress" depicted Democratic Party leader and former U.S. President Andrew Jackson leading a donkey, carrying presidential candidate James Polk and vice-presidential running mate George Dallas to the "Salt River," a figure of speech for political disaster (Johnson, 2011, pp. 11-12).

\section{MUSICAL ADAPTATIONS}

In 1941, Frank Mott Harrison identified more than 150 poetic or dramatic versions of The Pilgrim's Progress, and that number has continued to grow over the past sixty years. For example, of the five operas composed by Ralph Vaughan Williams, one is the Pilgrim's Progress, a morality play comprised of a prologue, four acts, and an epilogue and forty-one individual singing roles. It was first performed in 1951 at Covent Garden, and several recordings of this opera have been produced, including versions performed by the City of London Sinfonia, the Royal Opera Chorus and the Orchestra of the Royal Opera House, and the London Philharmonic Orchestra and Chorus. In addition, David MacAdam of New Life Fine Arts (affiliated with a community church in Concord, Massachusetts) in 1992 debuted a presentation of his musical adaptation of The Pilgrim's Progress that includes events from Bunyan's life. In Gaithersburg, Maryland during the spring of 2009 a talented group of high school students at Covenant Life Church performed Pilgrim, a modern musical adaptation of Bunyan's allegory. Based on a script written by Janice Mays and Cathy Mays, God is a character in the play and is Christian's constant traveling companion. The audience can see God accompanying the pilgrim but Christian cannot, although he occasionally hears God's voice and heeds it. Also, rather than leaving his family, a youthful Christian leaves a party filled with his temporal-minded friends to commence his journey to heaven.

\section{CINEMATIC ADAPTATIONS}

Over the past century there have been several cinematic adaptations. In 1912, for example, a black and white, silent film version of The Pilgrim's Progress was produced. One advertisement in the Evening Post billed it as a "true to life adaptation of John Bunyan's famous book. A story which appeals to young and old alike - a story wonderful in its conception yet simply told," promising its viewers "a film which tells an Enthralling Story and conveys a Powerful Moral Lesson" (p. 8).

Later in the twentieth century, Ken Anderson wrote, produced, and directed the film Pilgrim's Progress (1977), featuring actor Liam Neeson in his cinematic debut. The story begins with Pilgrim wandering through a forest, wearing seventeenth-century costume, and carrying a book in his hand and a large burden on his back. A chorus of voices softly chant repeatedly the phrase, "The wages of $\sin$ is death." The third-person narrator declares 
that the enemy, Apollyon, who is seen dressed in a cape with a bushy mustache, goatee, and long pointed, painted fingernails, will be the cause of Pilgrim's "many trials and disappointments." Throughout the film, Apollyon lurks about, spies on, and follows the pilgrim along his journey. Even in the House of Interpreter, after Pilgrim is shown a painting of the faithful man with a crown above his head and the allegory of the dust on the floor, Apollyon appears inside the house and steals Pilgrim's book and tosses it toward a burning fire, but the book magically reappears, safely in Pilgrim's hands.

In another scene, while reading his book, Pilgrim glances at a hill and sees a huge cross. As he begins walking up the hill, he sees Jesus hanging and suffering on the cross. Removing his hat, Pilgrim gazes intently at the cross and falls to his knees. Jesus cries, "Father, forgive them." Immediately, Pilgrim echoes fervently and emphatically, "Forgive me." At that, his burden is released from his back, and it rolls down the hill. His old book changes into a book with a new binding, and he also receives a new name - a voice from heaven declares: "your name shall no longer be Pilgrim. Your name shall now be Christian."

After Faithful joins Christian, together they enter Vanity Fair, where they observe an abundance of shallow laughter, food, drink, and expensive clothing. Featured activities in Vanity Fair are jousting, puppet shows, and sword fighting. Those living in Vanity Fair come out to mock Christian and Faithful, and they snatch Christian's book, open it up, and begin laughing about its contents, then toss it about, playing a game of keep away and teasing the two travelers. Meanwhile, Hopeful watches Faithful and Christian in Vanity Fair, and both are condemned to death. Hopeful picks up Christian's book lying on the ground and he reads it; the key of Promise lies next to the book. As Faithful is burned at the stake, Hopeful helps Christian escape from Vanity Fair.

Rather than present Christian's battle with Apollyon early in the pilgrimage as Bunyan does in his allegory, the creators of this film stage that significant encounter as a climatic fight against evil in the penultimate scene, just prior to the pilgrims' entrance into the Valley of Death. Heeding the advice of the whispering chorus of voices, Christian takes up the shield of faith, and when his book turns into a sword, he grabs it - the sword of the spirit, the word of God-in his battle against Apollyon, who hurls darts of fire at Christian. After successfully defeating his enemy, the narrator states, "The battle is not yours, the battle is the Lord's."

This marks the end of the journey, as whispering voices punctuate the reward that awaits them: "Now there is in store for me the crown of righteousness." Instead of wading through the River of Death, both Christian and Hopeful follow Evangelist through the Valley of Death and disappear inside a cemetery. The closing scene takes place in the cemetery and shows Apollyon sitting down, berating himself, saying: "I lost them, they should have been mine." He then points to the tombstones, representing the souls of those who he claims are his. The narrator warns, "Now he looks for his next victim" as Apollyon's eyes look into the camera. Apollyon points at the viewer and says, "There's a possible victim. Of course, of course...you!"

Neeson plays not only the role of Evangelist but also of Help, Jesus, Mr. Goodwill, Mr. Interpreter, and the shepherd, Knowledge - all characters who assist Pilgrim during his journey. Since Neeson plays both Evangelist and Jesus, it is readily apparent that Evangelist is a representative servant and voice for God. Because the same actor is playing those roles, when Evangelist comes to rescue, direct, or reprimand Christian, it can be interpreted that it is God who is accomplishing that work through one of his servants. In contrast, Maurice O'Callaghan acts the part of Apollyon and other characters who endeavor to thwart Pilgrim in his progress, including Obstinate, Worldly Wiseman, and the Prince of Vanity Fair. Because Satan is depicted transforming into various characters it is clear which characters are evil and are speaking for the Archenemy. By doing so, this film emphasizes the persistent evil and temptations that Christian faces throughout his journey.

Because the film is so short - the running time is only 72 minutes - the filmmakers had to make decisions about what was most essential to tell their version of the story. For example, we do not see Pilgrim's family and we do not witness his departure from the City of Destruction. Only two of the four lessons are taught in the House of Interpreter. Talkative, the Palace Beautiful, and the River of Death are also omitted. Christian does not wear armor or carry a sword until the end when he battles Apollyon, when he is instructed to take the shield of faith and the sword of the spirit.

Similar to the 1977 film described above, Pilgrim's Progress: Journey to Heaven (2008) commences by presenting historical information about Bunyan and his bestseller, some of which is misleading. For example, it claims that The Pilgrim's Progress was written in 1675. According to Richard Greaves, Bunyan probably started writing The Pilgrim's Progress in March 1668 and must have completed part one by 1671 (Greaves, p. 218). The opening scene of this film (directed by Danny Carrales) shows Christian (played by Daniel Kruse) with a massive 
burden on his back, walking down the street of a suburban neighborhood, reading his book. A flame of fire comes down from the sky, barreling down the street, and flies right through him. Later, at the dining table with his wife and two young children, he tells his family that their city will be destroyed by fire. His wife begs him to stop reading the book, calling it a book of fantasy. She assures him that they are all perfectly safe, but Christian informs her that his burden keeps getting larger. After being told by his wife that he will sleep in the guest room, he experiences a restless night. He prays earnestly for relief. The next morning his kids are playing video games, and they refuse to listen to their father. The narrator interjects that Christian's children are "blinded by the things of this world."

At regular intervals between scenes throughout the film, a colorful map appears on the screen so the viewer can track Christian's progress and see where he is going. The film fulfills its advertised objective of rendering a faithful and creative adaptation of Bunyan's story. Although it primarily follows the plot outlined in the original allegory, a few notes summarizing the differences will suffice. After escaping the fiery arrows launched by Satan's army while passing through the Gate, Christian reaches the House of Interpreter. Instead of featuring a character like Bunyan's Man in the Iron Cage, one of the scenes shows a frightened woman, clutching her bedpost. She explains that her fear was caused by a vision she saw. In her vision, the call to judgment was issued, and the graves were opened; an army separated the good and evil on the earth, and she was left behind. She testifies that hell is real and that hell is where she is going.

At the Palace Beautiful (a scene omitted from the 1977 film), Christian is dressed in armor. Later in the Valley of Humiliation, Christian battles Apollyon, who resembles Darth Maul (e.g., horns, red eyes), the villainous character in Star Wars Episode 1: The Phantom Menace (1999). Similar to Bunyan's text, there is a battle of words between Christian and Apollyon. After Christian declares that he is prepared to die- "I will never turn my back on the King"- he stabs Apollyon with his sword.

Later in the film, after meeting Ignorance, Christian and Hopeful encounter a bright, radiant being, who they follow, but this "shining one" turns out to be Flatterer, and they are ensnared in his net. Finally, a true shining one comes to their rescue. Soon they are drowsily crossing the Enchanted Ground, so they engage in conversation to keep each other awake. Hopeful recalls his wild life in Vanity Fair, where he could not get enough of nice cars, women, and gambling until he "fell in love with Jesus." After entering into the Celestial City at the film's conclusion, the narrator announces, "We are all on the same journey. Are you on the right path?"

\section{CONCLUSION}

Since Bunyan's pilgrimage allegory first captured the imaginations of readers in the seventeenth century, copious continuations and adaptations have appeared in various forms. These retellings - whether recast in verse form, set to musical scores, expanded into novels, or dramatized on the stage or screen-may attempt to imitate or duplicate Bunyan's prowess as a storyteller. Regardless of their respective intentions, based on these numerous attempts, we can surmise that both artists and audiences over the centuries have been keenly interested in the message, the characters, and the drama contained in Bunyan's The Pilgrim's Progress.

\section{REFERENCES}

[1] Anderson, Ken, director. Pilgrim's Progress. Ken Anderson Films, 1977.

[2] B., J. The Pilgrim's Progress From This World to That Which is to Come: The Third Part. Printed by E. Millet for J. Deacon, J. Back, and J. Blare, 1693.

[3] Bunyan, John. The Pilgrim's Progress, $11^{\text {th }}$ edition. N. Ponder, 1688.

[4] Carrales, Danny, director. Pilgrim's Progress: Journey to Heaven. DRC Films, 2008.

[5] Cook, Susan Deborah. 'The Pilgrim's Progress: Its Influence on and Relationship to Religious Fiction, 16781710.' Doctoral thesis, London University, 1997.

[6] Garrett, Christopher E. "How T. S. Became Known as Thomas Sherman: An Attribution Narrative." Papers of the Bibliographical Society of America 108, no. 2 (2014): 191216.

[7] Garrett, Christopher E. 'Imitative Sequel Writing: Divine Breathings, Second Part of the Pilgrim's Progress, and the Case of T. S. (aka Thomas Sherman).' Doctoral dissertation, Texas A\&M University, 2007.

[8] Greaves, Richard L. Glimpses of Glory: John Bunyan and English Dissent. Stanford: Stanford University Press, 2002.

[9] Harrison, Frank Mott. 'Editions of The Pilgrim's Progress,' Library (1941), 73-81.

[10] Hoffman, Francis. The Pilgrim's Progress...done into Verse. R. Tookey, 1706.

[11] Johnson, Galen K. 'The Pilgrim's Progress in the History of American Public Discourse," LATCH, 4 (2011), 1-31.

[12] Kaufmann, U. Milo. The Pilgrim's Progress and Traditions in Puritan Meditation. New Haven: Yale University Press, 1966.

[13] Keeble, N. H. The Literary Culture of Nonconformity in Later Seventeenth-Century England. Athens: University of Georgia Press, 1987.

[14] 'Pilgrim's Progress,' Evening Post (2 December 1912), 8. Retrieved from http://paperspast.natlib.govt.nz. 
[15] S., T. The Second Part of the Pilgrim's Progress. T. H., 1682.

[16] The Progress of the Christian Pilgrim, From this Present World to the World to Come: In Two Parts, $2^{\text {nd }}$ edition. Printed for the Author and sold by the Booksellers of London and Westminster, 1702.

[17] Tindall, William York. John Bunyan, Mechanick Preacher. New York: Russell \& Russell, 1964. 